\title{
Out of the testis: biological impacts of new genes
}

\author{
Kevin G. Nyberg and Richard W. Carthew \\ Department of Molecular Biosciences, Northwestern University, Evanston, Illinois 60208, USA
}

The study of newly evolved genes has long fascinated biologists, but large-scale studies of their expression dynamics and molecular function have provided conflicting interpretations of their biological impact. In this issue of Genes \& Development, Kondo and colleagues (pp. 1841-1846) use extensive transcriptomic resources and current CRISPR/Cas9 technology to re-examine the functional impact of newly evolved genes in Drosophila and find evidence of their biological impact on male reproduction.

Newly evolved genes are a major source of biological innovation, but assessing their impact on cell and developmental biology can be complicated. Older, deeply conserved genes typically show strong signals of purifying selection, and their disruption often results in severe, easily detectable phenotypes. New genes, however, may not be as deeply integrated into cellular and developmental processes and thus may display more subtle phenotypes and evidence of selection that is harder to detect. In this issue of Genes \& Development, Kondo et al. (2017) use the latest genomic and transcriptomic resources and CRISPR/Cas9 technology to identify and functionally assay newly evolved genes in Drosophila.

Gene duplication provides the crude genetic material for the evolution of many, if not most, new genes /Ohno 1970). In most cases, the new copy will deteriorate and become a pseudogene, while the parental copy remains unchanged. Alternatively, one copy maintains the ancestral function, while the other acquires a novel function. However, this process of neofunctionalization often makes it difficult to computationally distinguish a new gene from its parent when using whole-genome alignments. Kondo et al. (2017) performed extensive manual verification of computationally derived alignments to distinguish new genes from putative parents in the whole-genome alignments of Drosophila species. Using this approach, they identified $>1100$ new genes that have originated in the past 40 million years of Drosophila evolution, many of them identified for the first time.

[Keywords: Drosophila; gene evolution; spermatogenesis; testis] Corresponding author: r-carthew@northwestern.edu

Article is online at http://www.genesdev.org/cgi/doi/10.1101/gad.307496. 117.
Using the extensive RNA sequencing (RNA-seq) data generated from the modENCODE project, Kondo et al. (2017) showed that new genes are more likely to be expressed in fewer tissues than older genes (Brown et al. 2014). Furthermore, new genes tend to show highest, if not exclusive, expression in the testes or male accessory glands. Their observations are consistent with previous observations of testis-biased expression of new genes in mammals and flies that support the "out of the testis" hypothesis for new gene evolution.

The "out of the testis" hypothesis posits that unique genomic features and powerful selective pressures in the male germline encourage the creation of new genes (Kaessmann 2010). In the male germline of mammals, several factors contribute to a genome that is permissive for the expression of new transcripts, including histone variants and modifications, global demethylation of CpG islands, and elevated expression levels of transcription machinery (Kleene 2001). Selective pressures such as sperm competition, sexual conflict, and infection from germline pathogens underlie the rapid evolution of male reproductive genes (Haerty et al. 2007). Once actively maintained, these testis-specific new genes may eventually be expressed and acquire functions in other tissues or developmental contexts.

It is then reasonable to expect that mutations in testisspecific new genes would predominantly cause specific defects in spermatogenesis and male fertility. However, a 2010 study by Chen et al. (2010) found that knockdown of $30 \%$ of new Drosophila melanogaster genes via RNAi resulted in lethality, a percentage that is equivalent to genome-wide estimates of lethality (Miklos and Rubin 1996). Chen et al. (2010) concluded that many new genes are quickly integrated into regulatory networks that are necessary for viability.

Kondo et al. (2017) have been able to reassess the biological roles of new $D$. melanogaster genes. They found that many of the new genes identified by Chen et al. (2010) show biased or exclusive expression in the testes or male accessory glands, regardless of whether they were

(C) 2017 Nyberg and Carthew This article is distributed exclusively by Cold Spring Harbor Laboratory Press for the first six months after the full-issue publication date (see http://genesdev.cshlp.org/site/misc/ terms.xhtml). After six months, it is available under a Creative Commons License (Attribution-NonCommercial 4.0 International), as described at http://creativecommons.org/licenses/by-nc/4.0/. 
shown to be necessary for viability. Since RNAi can produce off-target effects, Kondo et al. (2017) chose to reassess the viability of these select new genes using both independent RNAi transgenes, where available, and early frameshift mutations introduced using the CRISPR/Cas9 system. Their RNAi failed to phenocopy the lethality of previous gene knockdowns in the majority of cases, and Kondo et al. (2017) were unable to observe lethal phenotypes in frameshift mutants of 24 new genes. To verify the efficacy of their functional tests, they also generated frameshift mutations in old and essential genes and generated lethal phenotypes in all but one of these.

Since many of the 24 new genes tend to be expressed in the male reproductive system, Kondo et al. (2017) looked for disruptions in male fertility or testes cytology of the mutants. Mutation of Prosa4T1 resulted in complete male sterility, and closer examination of testis morphology revealed that the sterility likely occurred from disruption of sperm individualization. Mutations in a second new gene, $S p n 77 B c$, also resulted in defects in sperm individualization, although these appeared less severe than mutations in Prosa4T1 and did not affect male fertility.

Since phenotypic analysis may miss subtle defects, further evidence of new gene functionality was obtained by looking for evidence of selection on gene sequences. If a new gene has little functional impact on the species, then its coding sequence should neutrally evolve. Instead, Kondo et al. (2017) found evidence of adaptive evolution of new gene sequences using both the $\mathrm{dN} / \mathrm{dS}$ metric and the direction of selection statistic. The strongest evidence was observed for new genes restricted to the male reproductive system.

Advances in genomic resources and experimental technologies such as the CRISPR/Cas9 will facilitate the reexamination of old questions. Here, Kondo et al. (2017) provide fresh insights suggesting that newly evolved genes can quickly impact the biology of male reproduction.

\section{Acknowledgments}

Research in the Carthew laboratory is supported by the National Institutes of Health (GM118144 to R.W.C., and GM122349 to K.G.N.).

\section{References}

Brown JB, Boley N, Eisman R, May GE, Stoiber MH, Duff MO, Booth BW, Wen J, Park S, Suzuki AM, et al. 2014. Diversity and dynamics of the Drosophila transcriptome. Nature 512: 393-399.

Chen S, Zhang YE, Long M. 2010. New genes in Drosophila quickly become essential. Science 330: 1682-1685.

Haerty W, Jagadeeshan S, Kulathinal RJ, Wong A, Ravi Ram K, Sirot LK, Levesque L, Artieri CG, Wolfner MF, Civetta A, et al. 2007. Evolution in the fast lane: rapidly evolving sex-related genes in Drosophila. Genetics 177: 1321-1335.

Kaessmann H. 2010. Origins, evolution, and phenotypic impact of new genes. Genome Res 20: 1313-1326.

Kleene KC. 2001. A possible meiotic function of the peculiar patterns of gene expression in mammalian spermatogenic cells. Mech Dev 106: 3-23.

Kondo S, Vedanayagam J, Mohammed J, Eizadshenass S, Kan L, Pang N, Aradhya R, Siepel A, Steinhauer I, Lai EC. 2017. New genes often acquire male-specific functions but rarely become essential in Drosophila. Genes Dev (this issue). doi: 10.1101/gad.303131.117.

Miklos GL, Rubin GM. 1996. The role of the genome project in determining gene function: insights from model organisms. Cell 86: 521-529.

Ohno S. 1970. Evolution by gene duplication. Springer Verlag, Berlin. 


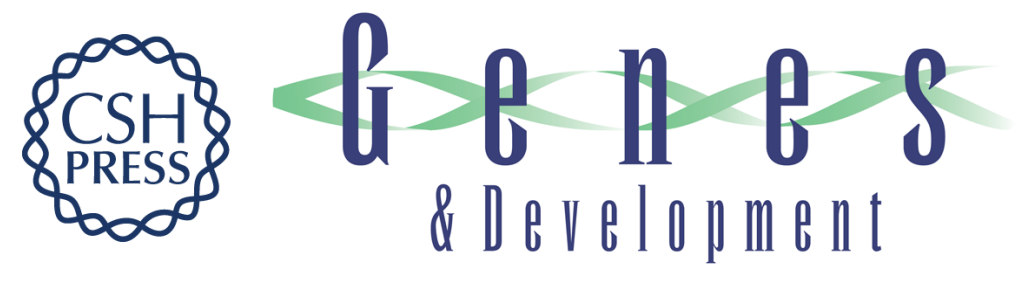

\section{Out of the testis: biological impacts of new genes}

Kevin G. Nyberg and Richard W. Carthew

Genes Dev. 2017, 31:

Access the most recent version at doi:10.1101/gad.307496.117

Related Content New genes often acquire male-specific functions but rarely become essential in Drosophila

Shu Kondo, Jeffrey Vedanayagam, Jaaved Mohammed, et al.

Genes Dev. September , 2017 31: 1841-1846

References This article cites 7 articles, 3 of which can be accessed free at:

http://genesdev.cshlp.org/content/31/18/1825.full.html\#ref-list-1

Articles cited in:

http://genesdev.cshlp.org/content/31/18/1825.full.html\#related-urls

Creative This article is distributed exclusively by Cold Spring Harbor Laboratory Press for the first

Commons six months after the full-issue publication date (see

License http://genesdev.cshlp.org/site/misc/terms.xhtml). After six months, it is available under a Creative Commons License (Attribution-NonCommercial 4.0 International), as described at http://creativecommons.org/licenses/by-nc/4.0/.

Email Alerting Receive free email alerts when new articles cite this article - sign up in the box at the top Service right corner of the article or click here.

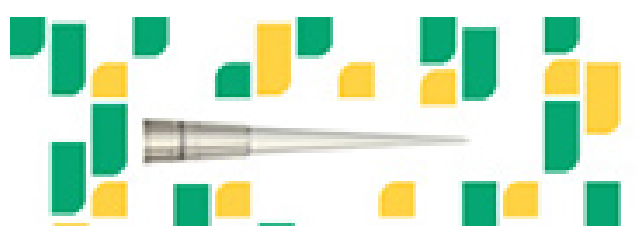

Focused on your science. 